\title{
COMMERCIAL ASPECT OF SPORT EVENTS
}

\author{
MAREK ZAWARTKA
}

\begin{tabular}{l|l} 
& $\begin{array}{l}\text { The Jerzy Kukuczka Academy of Physical Education in Katowice } \\
\text { Faculty of Physical Education } \\
\text { e-mail: marek.zawartka@op.pl }\end{array}$ \\
$\begin{array}{l}\text { RECEIVED } \\
\text { JELEPTED }\end{array}$ & $\begin{array}{l}25 \text { March } 2015 \\
6 \text { November } 2015\end{array}$ \\
CLASSIFICATION & $\begin{array}{l}\text { L83, M00 } \\
\text { KEYWORDS }\end{array}$ \\
ABSTRACT & $\begin{array}{l}\text { Sport through its multilateral character has become a kind of phenomenon, which co-creates the image of } \\
\text { contemporary mass culture. Sports all the time is in the process of professionalization and commercialization, } \\
\text { which leads to competing athletes and sports clubs in order to maximize financial returns. Sport has become } \\
\text { an important element of the economy, strongly influencing the production area, sports facilities and sports } \\
\text { equipment. It is subject to the universal rules of the game market, including commercialization, rationalization, } \\
\text { professionalism, bureaucracy, entertaining etc. (Guttmann, 1995). The purpose of this article is to show sport- } \\
\text { ing events in a slightly different dimension than is traditionally perceived, as a business, which can earn all } \\
\text { stakeholders involved in the co-creation. }\end{array}$
\end{tabular}

\section{Introduction}

Today sport is both multilateral nature (cultural, sociological, health, spectacular), but it is also a phenomenon that co-creates an image of contemporary culture. It is also important to the economy, strongly influencing the production area, sports facilities and sports equipment. It is subject to the universal rules of the game market, including commercialization, efficiency, professionalism, bureaucracy, spectacular, etc. (Guttmann, 1995). At the 
same time modern sport - because it is part of physical culture - is in the process of systematic and dynamic changes. At its base there is a lot of reasons, one of which the most important is the progressive commercialization. Its importance in daily life is very important and affects social mix. Sport became an entertainment for a growing group of discerning people. The vast majority of society is committed by practicing or watching, in anticipation of a high quality product. It combines health with valuable educational aspects. Their classic value, which was to improve physical fitness, maintaining good health, went hand in hand with the ethos of honor, cultural rules and fair play. However, as has become a business, and its relationship with the economy are very clear, these values may be limited by the desire to achieve sporting success at any price. A sport is in the process of professionalization and commercialization, leading to transform it into a competing athletes and sports clubs in order to maximize financial returns. Clubs are businesses, sport event is a business, and those of the management of sports organizations are forced to respond to the changing environment, strongly collaborate with the business. Widespread interest in the sport recognized the media and made an important incentive for attracting customers. Performing transmission, their reach to the sport, attracts sponsors and advertisers, which means more and more money. As a result, the level of sport events constantly increasing, players are motivated by high wages to work hard and fierce competition on the high-level sport, and thus increase the interest of fans.

\section{Literature review}

Sports event in addition to a high level should provide an adequately high level of organization (Doktor, 1996). This is a challenging and contemporary influence on Entrepreneurship sports managers, who - besides financial results of Sports a Joint Stock company and its outcome sport - should be oriented into a business offering goods (products) of the highest quality. The consequence of this is the need to meet the increasingly high expectations of the organizers of the participants in these events, especially in the purchase of the product offered to them (Panfil, 2004: 50-52).

Clearly emphasized the role of the buyer should encourage everyone involved in the product development process to ensure the highest quality of its (value). In this sphere, recognizes the need for professionalization process of organizing sports events. Sports event is a phenomenon that attracts many spectators on the stands. However, apart from sport motives they are guided by a number of other factors, causing them to compete. Another important element of inclining to participate in the event is an extraordinary opportunity to experience emotional arousal, which vanish the barriers of gender, age, education or culture. This state is called the rapture affiliation audience. Accompanied by a further result of the consolidation audience who can also provide other participants in the show (Zdebska, 2008). The show is also the phenomenon of a commercial nature, where beyond sport rivalry, competition takes place on the basis of the business, because sport has ceased to be a purely "physical game based on talent mobility" (Krawczyk, 2000: 77).

Managing today's sports organizations involved in the game market fought in battle not only with the highest number of customer's spectators, but also to achieve a profit for its shareholders. The need to improve the effectiveness makes it advisable to use marketing approach, the identification of the needs of consumers in the market to adapt to these marketing activities, as well as creating new needs with specific marketing instruments. According to Guy Lewis and Herb'a Appenzeller a sport marketing is "the use of a composition of marketing tools to communicate with customers and identify benefits of sport and participation in sport spectacles" (Lewis, Appenzeller, 2000). 
Theory of sports marketing, which is run by sports organizations means not only sporting success, but such actions that will lead to the development of the club and economic organization. Economic aspects have become a leaven to the emergence of new sectors of the economy - that is the sport perceived, in the form of services, property, information, places, or other people. (Waśkowski, 2005)

An Entrepreneurship organizer of sporting events is fundamental. Without a doubt attractive sports event requires, knowledge and application of the principles of sports marketing and high managerial skills (Waśkowski, 2004). „A classical example is football, because, football provides a standard management model, which lead only to the success of best practices" (Bolchower, Brady, 2007: 15).

It should be recalled British clubs; among them for many years at the forefront is Manchester United.

With its growing position in sports, progressing in parallel expansion in the business field and the number of fans is more than 330 million people around the world (Tręda, 2009). This is because the "United offers a product that (...) is characterized by high quality, and (...) has allowed the club to win loyal crowd of followers" (Tręda, 2009). In addition, in exchange for a relatively expensive ticket costing tens of pounds audience is guaranteed the right conditions, including a modern sanitary base, catering, setting of spectacle, as well as safety (Tręda, 2009). It seems that the commercial nature of the performances is particularly evident in the case of competition in team; the nature and popularity are to some extent a guarantee of success for the organizers. The Sports market is a double dual market. Sports organizations operate simultaneously on two levels: market for sports and sponsorship advertising market. The sports market, where the buyers of products are individual consumers (fans), clubs sell them on the primary (during sporting events) as well as on the secondary market (eg through the media).

Exciting sport events and the friendly atmosphere guarantee a win new fans and sponsors whose support will further professionalize the organization of sports events.

\section{Analysis}

Nowadays, the sports club is not only a team but increasingly vital enterprise. Changing market demands from CEOs, managers, clubs managers to react flexibly to changing environments. Depending on budget collected, clubs may or may not afford the contracting of players to ensure an adequate level of sports. This is a vicious circle because the only clubs with sports ambitions and the prospects for success are able to be interested in their offer a potential sponsor.

That is why is so important in today's sport the image of the club, functioning on the sports market in Poland. Building the image of a strong and reliable partner may take years, which does not give any assurance to succeed. The image should build as much as possible, in small steps, gradually, to achieve full success. An important role is attributed to the activities of public relations, which in addition to the construction of channels to communicate with the fans, the club also serve to promote safe sporting spectacle. Moreover, they are important, "action aimed at increasing the market value of the individual components of the sports club, or players, sports team, or a trade show", responsible for, the creation of public, media, sponsors and supporters of the positive image of the product (Panfil, 2004).

The positive image of the following functions:

- carries the nature of the product and is an important factor in making important decisions chosen by buyers,

- provide customers additional advantages, such as, advantages associated with prestige, 
- allows you to make differentiation brands, products and companies themselves conducive to their individualization and the creation of business identity,

- promotes the formation of confidence in the company, which for buyers of its products is reducing the risk when deciding to purchase (Sznajder, 1996, p.83-84).

Correct the image of a sports club is created among the various marketing activities of sports, and especially its promotion. This all contributes to the development of the image. The business of sports organizations, there are different forms of promotion, the most important are:

- advertising,

- public relations activities,

- supplementary promotion,

- acquisition,

- sponsor,

- product placement (Sznajder, 2012).

The promotion associated with the formation of the image of a sports organization. However they are certainly, handled in different ways depending on the level of the sport and the development of a sports club.

The promotion can be divided into two basic groups:

- economic objectives, as measured by volume or value of sales of sport,

- objectives of information, of achieving a specific change in the image of the club or brand (Sznajder, 2012).

Highly developed sports clubs found in extra leagues of football, volleyball, basketball, handball, put more emphasis certainly on the economic objective. Entrepreneurial managers optimize their activities aimed at attracting the stadium, a sports hall as many fans who purchase a ticket (pass), club t-shirt and gadgets for children, and in the case of football, they go during break time into the restaurant or bar. This type of promotion is directly reflected in the income of the club, relating to the sale of products offered by the club. Work on the strong brand starts from the beginning of the sports club with ambition and prospects for development. Keep the best possible image, even before the major sports results. In this way, the way to build a group of loyal fans, buyers of club products will be shorter, simpler and less costly. Proper care of the flow of information, communication with the immediate environment, fans, and especially the media, will enable us to think about obtaining sponsors who make it possible to build a foundation for the development of sports.

Certainly an important element of the promotion, which strongly affects the image of the club are the sports results achieved by the team and its organizational structure. Sporting successes achieved by the team, they are on the outside, proof of the effective operation of the club, a good selection of the coaching staff, players, providing adequate conditions for work and development. This club is positively perceived by potential sponsors, is slowly becoming a solid player in the market of sports.

Sports organizations vary greatly as to the purpose of the operations, legal status, organizational structure, scope of action, relevance to the functioning of the sport, how to make decisions. Objectives are varied depending on the type of sports organization and strategy of the manager. In the case of sports clubs can specify four basic objectives of:

- Sports Victory,

- Financial profits, 
- Satisfaction club managers or other sports organization of governance, as evidenced by a number of sports trophies,

- Integration of the local environment (Sznajder, 2012: 59-62).

The most important factor leading to the achievement of the objectives manager is the ability to establish a hierarchy of values and relationships between the different objectives.

Profits generated by the sports club managers are derived from two main sources resulting sense of duality sports market:

- Fans (customers),

- Sponsors/Business Partners.

Nearly $70 \%$ percent of companies are choosing to sponsoring events. This involves certainly a small risk, to participate in a one-off, or even cyclical, large sporting event. This is also a chance to show up among the other major sponsors, which can in a positive way to build your company brand. This type of events, in practice, is a $100 \%$ success in organizational and media result. Single part in the event can intensify the promotion. It is also not bear the risk associated with athletic performance achieved by the sponsored team and possible, the possible events in the stands during the weekly league games.

If a company treats sponsorship, as an important part of their promotional activities should clearly identify the goals that they wants to achieve. The main objectives of sponsorship include:

- raise awareness about the company and its products to potential consumers,

- establish a corporate image,

- improve existing corporate image,

- a positive association with the company taking, sponsorship activities,

- reach out to a selected group of consumers,

- entry into the local community and its association with special needs,

- increasing motivation and positive identification with the company among employees (Berbeka, 2004).

In creating the image of a company or brand through sponsorship, an important element is the use of a positive image of the sponsored and transfers it to the sponsor. Keeping such sponsorship policy, proving once again that one of the most important factors is the image of the sponsored entity. Positive sheath around the club, exciting sport events and a friendly atmosphere in the stands perpetuate among viewers very good reception in support of exciting events companies and help them make a decision about buying products and use their services from companies which support the club.

The main purpose of sponsoring companies is to build a brand image and to increase in awareness and brand awareness. Followed by more than $40 \%$ were due to brand loyalty, acquire new customers and increase in sales. In Poland, sport sponsorship is seen positively, as something natural. People think that by sponsoring the condition of Polish sport is better. This allows companies and businesses to get involved in sponsorship are well received by fans, and therefore potential customers. Supporters clubs, expect today to support their teams by business. State budget is not able to bear the costs associated with sporting activities and the expectations of sporting and economic success by enterprising managers and supporters, grow in proportion to the profit expectations of the players. Therefore, companies supporting sports clubs often are treated by the fans as the benefactors who pulled out a club from a hard economic situation. This has a very positive effect on the identification of the fans with the sponsor, wearing his colors, the purchase of its products, transfer the image from sponsored to sponsor proceeds 
very smoothly. Conversely, the situation looks for sponsors who are engaging in a form of personal sponsorship, initially displace the name, later from the stands the historical name of the club (Delecta-Chemik, ZAK-Mostostal, Bogdanka-Górnik, Dospel-GKS). In such cases, the sponsor's image significantly loses value, because very often the club's board has trouble convincing fans to the new name. And it would seem that anyone who comes to the club with the money can decide on changes in the image...

The company - the sponsor does not have to invest in advertising campaigns aimed at creating a certain image, and on the other hand, the customer is more willing to accept and believe moved through sponsorship value than those created by advertising (Sponsoring...).

In the process of image creation, uses the phenomenon of the transfer. In this case, an image without lasting long, risky and costly especially in the media is transferred from one entity to another.

This is done by using a synergistic effect. The essence of sponsorship lies in the fact that, thanks to combination of sponsored, the sponsor may create their own image transferring to a company-sponsored entity (Internet w działaniach...). The sponsorship of both the sponsor and the sponsored become partners in a relationship associated with the transfer of the desired value from the sponsored on the sponsor. The task of the sponsor is to ensure the presence of connecting with sponsored project and, where necessary, the transfer value of the brand (Meenaghan, Shipley, 1998).

Sponsor of high brand values, it is more recognizable than the sponsor of the low value of the brand, and thus more desirable and appropriate. We must also remember that the sponsor may be automatically transferred negative image, especially in continuous sponsorship, which may be the result of negative actions sponsored.

One of the conditions for the effective transfer of image-sponsored on the sponsor is a strong identification with the club supporters and their identification with him. This ensures that the sponsor easy and quick transfer of the image of a sports organization for their needs. Mutual activities are also beneficial when both the sponsor and sponsored operate in much the same way in similar markets and also in geographical terms. Sponsor, who conducts its business abroad, it will begin working with sponsored which will give him such promotions in European cups. Much easier to build a positive image of the company's exclusive sponsorship or personal. The logo and name of the sponsor, its brand, and in recent years the products are heavily exposed, alone, with a team or sporting event. There is no conflict with lots of logos, names of sponsors, easier to associate one sponsor, than the whole harmony of the companies. Certainly co-sponsorship is more a problem of smaller companies with brand, which cannot beat on the market. These larger, firmly planted on the market even in a wider circle of sponsors will be find. In the current situation of sports sponsorship market situation in which clubs or sporting events are the dozens of sponsors is virtually unavoidable.

Depending on the form of sponsorship benefits can be defined as:

- financial sponsorship - money transfers,

- sponsorship in kind - the transfer of various types of equipment,

- sponsorship of service - providing specific services for sponsor.

Become very popular in recent years, sponsorships in-kind and of service. Companies are likely ready to pass non financial measures, while clubs such a form of help accepts, realizing that otherwise would have had to bear the costs associated with the purchase of sports equipment or the use of transport services. No transfer of funds to sporting club does not imply a lack of opportunities for sponsors to benefit from similar financial benefits, as in the case of companies incur certain capital flows. Details of cooperation contained in the agreement 
are valued, and the club on the basis of which the company referred to promotional measures, according to athletic performance. Finally, the risk of corruption scandals in sports (mainly football). Ultimately, however, $61 \%$ of companies declare support for clubs and sports associations, so the analysis of this case is overwhelming preponderance of positive aspects of the sponsoring institution. Sponsorship of individual athletes carries $44 \%$ of the companies, which represents almost half of the respondents. In our country there are few individual athletes, who provide a combination of media attention with the success in sports: Agnieszka Radwańska, Kamil Stoch, before the accident - Robert Kubica. After leaving the Hill by Adam Malysz seemed ski jumping will lose the audience. Fortunately for the sport, for the players and ski association appeared Kamil Stoch, who achieves very good results. In the break in starts of Robert Kubica in Formula 1, its viewership dropped significantly.

By building its image, the sponsor should certainly clearly specify the nature of the sport, in which he wants to get involved or sporting event, which endorses its own brand. Specific disciplines associated with specific characters of its participants and audiences:

- golf, sailing - exclusive,

- hockey, basketball - dynamism,

- sport climbing - efficiency,

- handball - tough fight.

The right choice of sport will almost immediately transfer the image of the sponsor. The vast majority of companies would like to sponsor such clubs and sports projects that are attractive, strong in sports and guarantee success. Sponsorship of sports teams brings both significant benefits and risks. The Research conducted by the Pentagon study, the vast majority of companies through sponsorship want to build a brand image, increase their awareness and knowledge.

In the case of teams, is very positive aspect of the emotions, which accompany of league game at a high level. Crowds of fans in the stands cheering for the club and / or sponsor, the team has a positive impact on the image of companies directly involved in working with a team. Particularly well received is the behavior of fans during the meetings: volleyball, basketball, and handball. Risk, in the case of sponsorship of sports clubs and associations is the possibility of degradation, lack of interest in reaching satisfactory team supporters. Entrepreneurial activities of sports organizations in sports market, it is not sufficient to provide adequate returns, so it is necessary to raise funds outside of the sponsors. For sports organizations, leading marketing, sponsorship is one of the products it sells to sponsors, thereby generating revenue for your business.

In the development of sponsorship and its effectiveness is important to interest the three partners:

- companies applying this form of promotion - sponsor,

- the organization operates in order to obtain such a partner - sponsored,

- media relations returning from sponsored events.

Influence each other triangular elements of sponsorship are very high. Without the participation of the media interest in the sponsorship of business, any sporting events would be small. Sponsor has the aim to achieve the effects of publicity in relation to the target group of customers and does so by working with a sports club, which has its own circle of influence. Due to the dynamic development of the sponsoring companies increasingly affect the operation of sports clubs, team names, structures and legal form of the club. In addition, sponsoring sporting events have an impact on the terms of their performance, hours of television transmission. Therefore, some federations have even led to changes in rules of the game, rules, so as to adapt them to changing market realities. 
As already mentioned the image of sports events is built very strongly by coating both media, organizational, social and fans formed around specific sporting events. Still the biggest beneficiary of income from sponsors is football (in 2011, 44.4\% of companies issued on football sponsorship 200-250 mln PLN) (Możdżyńsk, 2011).

It is still the most popular discipline in our country, most often shown in the media, so that exposure Football Sponsors in the media in 2012 amounted to 1.16 billion PLN (Pentagon Research, 2010).

There are new stadiums, the atmosphere in the stands is becoming more friendly and "corruption scandal" - even though the stigma is still firmly imprinted - Polish football has it probably behind. This means that large companies still prefer to finance football. However, to improve the tarnished image of football is not just about increasing safety during mass events. The big problem is too high contracts of players presenting even by Polish standards very average level. This is reflected in the results of both the Polish national team, and in particular the participation of club teams in European cups. Suffice it to say that we belong to the group of countries such as Armenia, Ireland, Bosnia and Herzegovina, Lithuania, which for the past 10 years do not have the team for the Champions League. Countries with a much smaller population than Poland, such as the Czech Republic, Hungary, Slovakia, Serbia, Romania. Could be able to watch live the best European club teams. We did not manage to do 17 years in a row. This means that around football there is still a lot of a negative emotion, this time not associated with the trend supporters, but showing the players as poorly trained, inadequately prepared for their profession, few involved in their daily work, while earning huge money. Companies less likely want to engage giant money earned by working 40 hours a week of their employees to clubs where they are spent on high salaries of the players. Transfer of the image in this case does not encourage sponsors to invest further funds. Studies also show that in the coming year's sponsor's attention and money can be.

From this statement it can be said that the greatest opportunities for growth will have volleyball. We are constantly expanding discipline that espouses a positive image in the media (Polsat). A well-managed central association, family atmosphere in the stands, and every game is volleyball festival. In addition, more and more international volleyball events at a high level take place in our country, and it attracts the media and thus the sponsors and advertisers. This gives a great chance for volleyball skip "overpaid" football, clubs built for a lot of money by private owners, who will soon not be able to bear alone the burden of maintaining such an expensive toy. Especially in the failure of sporting success on the European stage. This, combined with the negative image of the Polish Football Association and a little stereotypical, but still not very well received by fans of football can lead to a situation that some large companies investing in football decides to build its positive image for less money in the disciplines as mentioned volleyball, rebuilt by the Eagles of Wenta handball, motor sports, ski jumping, basketball. Maybe even move resources to an increasingly popular boxing.

\section{Conclusions}

Gain of business partners, which to a certain extent also the fans is the basis and the main purpose of the sports organizations. Attractive, nicely packaged product that is sport event, ensuring full coverage of all stands and advertising space dedicated for sponsors. This is the optimal model that brings significant revenue to the club, giving the chance to strengthen the team, improve infrastructure and professionalization of activities. This all means that the goods that we sell are even more attractive. To improve the image and quality of services increases the interest of business partners. Exciting performances, sudden twists and unforgettable experience for long remain in the minds of sponsors and most of all the fans that are willing to return to the sports arena to look for more unusual 
excitement. In this way, the client gradually identify with the brand, is happy to use the catering, shop with gadgets or other promotions offered by favorite club. In today's world of competitive sports is very important to build a good relationship between the club and its partners (fans, sponsors). Closer ties with the sponsors and fans let's hope that the next bid will meet with a positive reception of this particular group of customers. Respected partner would become the loyal and willing to accept new proposals from the entity with who has several years of relationship. Promote a favorable image of your club by a professional organization of sport events together with their shell and facilities are the most important challenges facing entrepreneurial managers, managing modern and developing sport organizations.

\section{References}

Bednarczyk, M. \& Marczułajtis-Walczak, J. (2013). Marka sportowa w promocji turystycznej regionów. In: Zarządzanie turystyką w kryzysie. Edukacja i marka. Warszawa: CeDeWu.

Berbeka, J. (2004). Marketing w sporcie. Kraków: Akademia Ekonomiczna w Krakowie.

Bolchower, D. \& Brady, C. (2007). 90-minutowy menedżer. Lekcje z pierwszej linii zarządzania. Poznań: Wydawnictwo Zysk S-ka.

Doktor, K. (1996). Widowisko sportowe - nowa (gorsza) jakość. Sport Wyczynowy, 11-12: 7-10.

Guttmann, A. (1995). The image of sport in North America. In: Images of Sport in the World. Cologne: German Sport University. Internet w działaniach sponsoringowych, www.sponsoring.pl.

Krawczyk, Z. (2000). Sport w zmieniającym się społeczeństwie, Warszawa: Wydawnictwo AWF.

Lewis, G. \& Appenzeller, H. (2000). Successful Sport Management, Carolina Academic Press.

Maráková, V. (2011). Imidž v cestovnom ruchu. In: Marketing cestovného ruchu. Banská Bystrica: Slovak-Swiss Tourism.

Maráková, V. (2010). Uplatňovanie nástrojov marketingovej komunikácie v strediskách cestovného ruchu. Habilitačná práca. Banská Bystrica.

Meenaghan, T. \& Shipley, D. (1998). Focusing commercial sponsorship on the internal corporate audience. International Journal of Advertising, 17 (1).

Możdżyński, A. (2011). Rajdy sponsorów. Forbes, 8.

Panfil, R. (2004). Zarządzanie Produktem Klubu Sportowego. Akademia Umiejętności Management \& Coaching.

Sponsoring - prosty sposób na popularność, www.sponsoring.pl.

Sznajder, A. (2012). Marketing Sportu. Warszawa: PWE.

Sznajder, A. (1996). Sponsoring, czyli jak promować firmę wspierając innych. Warszawa: Business Press.

Tręda, T. (2009). Nowoczesne zarządzanie klubem sportowym na przykładzie Manchesteru United. Poznań: Football Bizness Group. Waśkowski, Z. (2004). Ocena atrakcyjności widowiska sportowego. Poznań: Akademia Ekonomiczna w Poznaniu.

Waśkowski, Z. (2005). Relacyjny model rynku sportowego i jego marketingowe implikacje. Poznań: Akademia Ekonomiczna w Poznaniu. www.pentagon-research.com

Zdebska, H. (2008). Istota i wartości zespołowych gier sportowych. Studia i monografie AWF w Krakowie, 49.

Cite this article aS: Zawartka, M. (2015). Commercial aspect of sport events. Szczecin University Scientific Journal, No. 883. Service Management, 16 (2): 161-169. 
